\title{
JOHN HALES (1582-1656). A TOLERANT MAN LIVING IN AN INTOLERANT AGE
}

\author{
LEE W. GIBBs* \\ Professor Emeritus, Cleveland State University
}

\begin{abstract}
This article focuses upon the seventeenth-century English philosophical theologian, John Hales, who is all too often overlooked or forgotten at the present time. The thought of Hales on the relation of human reason to God's revelation in Holy Scripture is shown to be remarkably modern in many ways. The article also concludes that Hales's "Middle Way" of thinking and acting continues to be relevant to Christian churches throughout the world torn as they presently are with discord and dissention.
\end{abstract}

KEY WORDS: latitudinarianism, Calvinism, Arminianism, Synod of Dort, middle way

John Hales was a divine of the Church of England known after his death by the epithet "the ever memorable". His profound learning and his innate friendliness endeared him to his peers. In spite of his retiring life style and his innately quiet disposition he was continuously a popular dinner guest, often invited because of his wit, his poetry, and his lively conversation. His rare intellectual abilities and social charm were accompanied by a humble modesty and a love for studious retirement. He remained reluctant throughout his life to publish his views in the press. The manuscripts from the few of his sermons, which have survived were said to have been literally snatched from his hand by friendly listeners as he left the pulpit. Throughout his life he remained the retiring scholar. Three years after his death John Pearson, Bishop of Chichester, who also had been educated along with Hales at Eton College, Oxford, gathered and published a collection of Hales's sermons, letters, and miscellanies. The book was published under the title, The Golden Remains of the Ever Memorable John Hales of Eton College (1659). This 1659 volume was republished in three volumes with the title:

* LEE W. GIBBS is professor emeritus at Cleveland State University.

() EMANUEL UNIVERSITY of ORADEA

PERICHORESIS $10.2(2012)$ 
David Dairyimple, ed., Works of the Ever Memorable John Hales of Eton (Glasgow, 1765). Dairyimple's edition was reprinted in 1971 by the AMS Press in New York under the title: Collected Works of John Hales. This three volume 1971 AMS edition of Hales's Works is the one cited throughout the present article.

John Hales's life was primarily one of the intellect. He did not become a man of public affairs, like William Laud or Oliver Cromwell. He devised no political or doctrinal plan to cure all of the ills of the suffering humanity of his day. He had no faith in solving theological controversies by physical force. Christ's kingdom is maintained, he believed, not by the sword but by the Spirit, not by violence but by love, not by striving but by yielding. $\mathrm{He}$ was exemplary in living and dying, this, his credo.

Hales was a native of Bath where he was educated in the grammar school. He matriculated at Corpus Christi College at Oxford in 1597 at age thirteen. He took his B.A. degree from Oxford in 1603. That same year he was elected a Fellow of Merton College. In his studies he had shown proficiency in Greek. After taking holy orders in 1612 he was appointed lecturer in Greek at Merton. His preaching in the college was regarded as brilliant, and was also renowned for being punctuated with striking metaphors, but a weak voice detracted from its overall effectiveness. Nevertheless, he also acquired a reputation for his subtle disputations in philosophy and theology.

In 1613 Hales was elected a Fellow of Eton College. In that same year he was summoned to Holland as chaplain to the English Ambassador to The Hague, Sir Dudley Carlton: in this capacity he was commissioned to attend the Synod of Dort in the winter of 1618-19, where he sat in the gallery as a spectator so that he could report the proceedings of the Synod to the British Ambassador. ${ }^{1}$ This Synod was one of the high marks in the history of international Calvinism. The Synod had been convened by the States-General of the Netherlands to deal with and try to resolve the Arminian Controversy. Five sets of articles were passed by the Calvinist majority against the Arminians concerning the theological issues of: (1) unconditional election; (2) limited atonement; (3) the total depravity of human nature; (4) the iresistibility of grace; and (5) perseverance of the saints. ${ }^{2}$ In his report concerning the Synod of Dort, Hales concluded that the Calvinist and the Armeni-

John Hales, Collected Works of John Hales, III: 2-152.

Philip Schaff, The Creeds of Christendom with a History and Critical Notes, 3 volumes (New York, NY: Harper and Brothers, 1877), III: 550-97.

PERICHORESIS 10.2 (2012) 
an parties were disputing real theological dilemmas and he encouraged mutual toleration.

Hales's two years as chaplain to the Dutch Embassy did not seduce him away from his studious habits or launch him upon a public career, even though he had influential friends whose patronage would have been available to him. After his return to England from Holland he once again buried himself in his books while at Eton, content for the next twenty years with no higher office than his Fellowship. Though separated from the world in spirit, Hales was not in the least inclined to depression or melancholy, but delighted in good food and stimulating conversation. His income from his Fellowship was meager but sufficient to provide for his two primary needs, namely, his generosity to financially struggling students and to buy books for himself. He had an excellent private library and carried the content of his books so efficiently in his memory that one of his contemporaries, namely Anthony A'Wood, once called him "a walking library".

Though he remained a retiring scholar throughout his life, in 1636 Hales wrote his best known work, a short paper on "Schism and Schismatics". This remarkable treatise was not written by Hales for publication. It was rather, part of a private letter he wrote as an answer to a query raised by his friend, William Chillingworth (1602-1644). Chillingworth liked Hales's response on schism so well that he began to circulate it amongst friends. The manuscript of this paper was so widely circulated and later published under the title, "A Tract concerning. Schism and Schismatics: Wherein is Briefly Discovered the Original Causes of all Schism", that it came to the attention of Archbishop William Laud (1573-1645), who after recognizing its author's ability, invited Hales to an interview at Lambeth Palace. Laud had earlier been acquainted with Hales during their undergradduate days together at Oxford. Such was Hales's retiring modesty that Laud informed him at their meeting that he had thought him long since dead and chided him for keeping so out of sight and in the background. The interview ended with an offer for Hales to become one of Laud's chaplains. After his acceptance of Laud's offer, Hales was also, in the following year, persuaded with some difficulty to accept another offer of becoming a Canon at Windsor Cathedral. The offer of such an appointment to one holding the, by then, widely recognized inclusive views of Hales is, indeed, more than somewhat surprising, coming as it did from William Laud, who was certainly not in his day, or later, known for his tolerance. 
It was during the years while Hales was a Fellow at Eton and before the great English Civil War broke out in 1642 that Hales had joined the group of scholars who had gathered around Lucius Cary, Lord Falkland, whose estate at Great Tew near Oxford, had become an intellectual center. This influential group included Gilbert Sheldon, later to become Archbishop of Canterbury, George Morley, William Chillingworth and Henry Hammond. Cary, Lord Falkland, was born in 1610 and had come to Ireland during his father's term as Lord Deputy of Ireland from 1622 to 1629. In 1632, the younger Cary settled at his English estate and began to gather the group of men who shared his desire to study and who greatly benefitted from the free use of their patron's extensive library. The outbreak of the Civil War dispersed the Tew Circle as a group. Falkland, himself, went into Cromwell's army and was later elected to the House of Commons. Eventually, Falkland was appointed Secretary of State, only to lose his life in the Battle of Newbury in 1643.

Falkland and his associates in the Tew Circle were in agreement in attempting to liberate their thinking by rational inquiry from systematized theological formulations whether of the Protestant Reformation or of the Roman Catholic Counter-Reformation. Concerning this emphasis on the role of reason in the Tew Circle, Henry R. McAdoo, Bishop of Ossery, in his classic study The Spirit of Anglicanism has observed that, "It is part of the perennial paradox of Anglicanism that its theological method is involved with the freedom of rational inquiry. It was so of Richard Hooker in the sixteenth century, and at the time of Charles Gore and his colleagues at the time of the Lux Mundi debate during the nineteenth century". ${ }^{3}$ This view was also held by John Hales and the Tew Circle in the seventeenth century.

The members of the Tew Circle were in agreement that it was necessary to separate the saving truth revealed in Holy Scripture from what was regarded by all too many of their contemporaries to be "correct" or "orthodox" theology. For members of the Tew Circle, the relation between faith and reason was intimate and close but ultimately the authority of faith was affirmed to be greater for it can support its claims which are clear to reason once they have been advanced, but can never be supplied by reason alone. For members of the Circle, acquiring saving truth, reason requires the revelation contained in Scripture. 
In this regard, Hales's view of the Bible and its interpretation was quite remarkable for his own day. For example, E. A. George excerpted several fragment from Hales's sermon entitled, "Abuses of Hard Places of Scripture", and then construed them into the following cohesive paragraph:

In passages, which are ambiguous and doubtful, or of dark and intricate meaning, it is sufficient if we religiously admire and acknowledge and confess, neither affirming or denying either side... I have, I confess, the same disease that my first parents in paradise had, a desire to know more than I need. It shall befit our Christian modesty to participate somewhat in the attitude of the sceptic. Wise Christians should be content to wait patiently with confession of ignorance before obscure texts in the Scriptures. ${ }^{4}$

In 1640, only one year after Hales's appointment as Canon at Windsor, the Long-Parliament met, with its life-and-death struggle between the House of Commons and King Charles I. In the same fateful year in which the great Civil War began, Hales was ejected from his canonry at Windsor by a Parliamentary committee, which was zealous against all Royalist sympathizers. In 1645, Archbishop William Laud, who was so bitterly despised by the revolutionary nonconformists, was executed. In the year of Laud's death, Hales's good friend, William Chillingworth died while a captive of the Parliamentarian forces. Shortly after, by sequestration of college rents he lost the stipend for his Eton fellowship on which he had lived for years with his simple life. In 1649, Hales refused to sign the Solemn League and Covenant, the agreement reached between the Scots and English Parliament held in 1643, which turned out to be the high-watermark of triumphant English Presbyterianism. Hales was shortly thereafter publicly dispossessed of his Eton Fellowship. He then became tutor to William Salter, nephew of the Bishop of Salisbury at Riching's Lodge in Buchinghamshire, where, in cooperation with Henry King, Bishop of Chichester, a kind of college was being established with Hales as chaplain.

No enduring peace, however, was to be granted to the quiet scholar. He was hounded in his retirement by the Parliamentary order against harboring malignants. This beneficent man was obliged to leave Riching's Lodge and seek refuge back at Eton College in the home of the widow of a former 
servant at Eton who remained grateful to him for his former generosity to her and her husband. There, in 1656, he ended his days in obscurity and poverty.

A sermon delivered by Hales at St. Paul's Cross entitled, "Peace, the Legacy of Christ" is exemplary of his serenity in an atmosphere of conflict. ${ }^{5} \mathrm{He}$ begins by saying that his object in speaking is to urge his hearers to a gracious toleration of each other's imperfections. He continued by saying that theologians need to use more self-control, letting the cause of God which they defend to be dealt with in quietness and moderation, and not in violence of passion as if they were possessed by a demon, rather than inspired by the Spirit of God. The prayer with which Hales closes his sermon was based on the text "Peace I leave unto you" (John 14: 27), and is a fitting tribute to the inmost spirit of the man, John Hales:

Look down, oh Lord, upon thy poor dismembered church, rent and torn with discord and even ready to sink.... Direct thy church, oh Lord, in all her petitions for peace. Teach her wherein her peace consists, and wean her away from the world and bring her home to Thee: that all those who love Thy peace may at last have the reward of the sons of peace, and reign with Thee in Thy kingdom of peace forever. ${ }^{6}$

In such a prayer one may hear in the midst of the theological storms of his and our own present troubled time Christ's own words addressed to His disciples: "Peace be with you".

The balance and moderation of Hales's mind and spirit, reflected in his via media theology, prevented him from finding rest in any of the extreme positions of his day. His middle way position is clearly exemplified in his two most important works, namely, in his "Notes from the Synod of Dort" which he sent to Sir Dudley Carleton, the British Ambassador to the Netherlands, and also in his 1642 treatise on "Schism", which was published, as noted above, without his permission.

In his Notes from Dort to Carlton Hales seriously attempted to remain impartial, but his strong, innate negative reaction to the public wrangling over theological issues invariably shows through, along with the spirit of balance and moderation of his thought. At Dort, Hales had witnessed the triumph of High Calvinism at the expense of the Arminians. Anthony Farin-

$5 \quad$ Hales, Works, III: 1-28.

$6 \quad$ Hales, Works, III: 27.

PERICHORESIS 10.2 (2012) 
don, a close friend of his, later said that Hales had told him that he had gone to Dort a Calvinist, but often acknowledged to him in later life that he had been so greatly influenced by a powerful exposition of the Scriptural verse, "For God so loved the world" (John 3:16), delivered on the floor at Dort by Episcopius, the leader of the Remonstrant Party, that Hales, according to Farindon had told him repeatedly, "It was then and there that I bade John Calvin Good night!"7 From this time forward in his life the creative divine love and the human response of faith and obedience became dominant in Hales's theological thinking.

In bidding John Calvin "good night" at the Synod of Dort, Hales was not necessarily bidding Arminius "good morning". On the crucial theological issue concerning the divine decrees, which lay at the core of the controversy between the Calvinists and the Arminians, Hales recommended mutual toleration. His own thought was bold and broad enough to recognize and appreciate the truth to be found in both the Calvinist and the Arminian positions. Hales reported that both parties were teaching important truths concerning predestination:

Were we not ambitiously minded every one to be lord of a sect, each of these tenets might be profitably taught and heard, and matter of singular exhortation drawn from either; for on the one part doubtless it is a pious intent to endeavor to free God from all imputation of unnecessary rigors; and on the other side, it is a noble resolution to humble ourselves under the hand of Almighty God. ${ }^{8}$

The same moderation and balance which is found in Hales's thought on predestination recurs in his treatment of the Calvinist doctrines of original sin and the total depravity of human nature. He refuses to allow these doctrines to cause despair or to obscure the strong sense of the moral responsebility of individual believers. In this emphasis Hales was anticipating the more optimistic view of human nature and the greater practical belief in the role of reason, a view which he shared with the later seventeenth-century Cambridge Platonists.

According to Hales, if any individual person finds herself or himself morally or spiritually weak, it is through his or her own fault, not through depravity of nature. Original sin, for him is not wholly responsible for all personal wickedness. Hales admits that the sin of Adam and Eve, however di- 
sastrous for their progeny, was more than counterbalanced by the righteousness of Christ and His cross.

Let us sorrow no more for our loss in Adam: for is not Christ tenfold better unto us than all the good of Paradise? The loss of that portion of strength wherewith our nature was originally endued is made up with fullness of power in Christ... It hurts not us that Adam fell; nay our strength and glory is much improved that by Christ we are redeemed. ${ }^{9}$

In conformity with this line of thinking Hales's attitude toward the Christian of unworthy moral life was as gentle as that toward the Christian struggling with doubts and intellectual difficulties. He believed not in condemnation and separation from such persons, but in the friendly and sympathetic association of the good with the bad. He wrote:

There is no man so ill but has some good in him. We must take care that we do not mistake in thinking that there in nothing else but evil. For as they who work in gold diligently save every little piece that falls away wheresoever it be, is a thing so precious that every little spark of it deserves our care and cherishing.

In defending this broadness of outlook and reaction against narrow exclusiveness, Hales pleads, "Let it not offend any that I have made Christianity rather an inn to receive all than a private house to receive some few". ${ }^{10}$

As with his treatment of the Calvinist doctrines of original sin and the total depravity of human nature so likewise with regard to his thinking about the doctrine of the perseverance of the saints. Here again, Hales finds truth in both the Calvinist and the Arminian positions. He conceives of the purposes of God in a similar broad and inclusive way. "God's purposes", says Hales, "are not to be defeated as the one side [the Calvinist] rightly contends, and yet the other side [the Arminian] is right in contending that God's purposes do not infringe upon personal human liberty. Indeed this human liberty is the very means by which the divine decrees are brought about". Hales concludes this deliberation by saying:

Let no one presume to look into the third heaven, to open the books of life and death, to pronounce over preemptorily of God's purpose concerning himself or any other person. ${ }^{11}$

9 George, Seventeenth Century Men of Latitude, 40.

10 George, Seventeenth Century Men of Latitude, 41; see also Hales's Works, I: 64-76.

PERICHORESIS 10.2 (2012) 
At the time of writing his 1642 treatise on "Schism" Hales was striving to occupy a mediating position between the Anglican High Church Laudians and the narrow Calvinist dogmatism of the nonconformist revolutionaries. During this turbulent time the nonconformists, when they came to power, were dispossessing and persecuting the very conformists who had formerly so persecuted them. Hales begins his manuscript on "Schism" with the following statement:

Heresy and schism as they are commonly used are two theological scare-crows used to frighten away those who would inquire into a matter. Yet the things themselves are of very considerable moment, the one offending against religious truth, the other against charity, and therefore both deadly. ${ }^{12}$

Hales defines heresy more as an act of the will, than of reason; heresy is also affirmed to be a lie, that is, schism is not merely a mistaken intellectual position, but rather a wrong disposition. Diversity of opinions, he argues, should not prevent those who hold them from worshiping together. Hales's central, striking theme here is that when one seeks for the cause of schism, it will ultimately be found that the one who separates, not the one who causes the separation is the real schismatic. The greatest source of schism, Hales asserts, has been a deplorable emphasis upon adiaphora or non-essentials (whether in doctrine or in ceremony):

It hath been the common disease of Christians from the beginning not to content themselves with that measure of faith which God in the Scriptures has expressly afforded us, but out of a vain desire to know more than is revealed they have attempted to devise things of which we have no light, either from reason or revelation; neither have they rested here, but upon the pretense of church authority (which is none) or tradition (which for the most part is feigned), they have preemptorily concluded and confidently imposed on others the necessity of entertaining conclusions of that nature, and to strengthen themselves have broken off into divisions and factions. ${ }^{13}$

Hales was equally vigorous in his protest against Laudian ceremonialism and ecclesiasticalism. Hales found himself at one with the revolutionaries in affirming the invisibility and spirituality of Christ's kingdom, and in advo-

George, Seventeenth Century Men of Latitude, 39.

Hales, Works, I: 114-15.

Hales, Works, I: 125.

PERICHORESIS 10.2 (2012) 
cating simplicity of worship, and he roundly rejected the Laudian emphasis on uniformity of ceremony. Hales strongly believed that Laud's position was not only illegitimate but also dangerous, for, he argued, the illegitimate introduction into liturgy of controverted ceremonies was a powerful incentive for provoking schism. Elaborating upon this issue, Hales wrote:

When liturgies were so framed that they admitted not of particular and private fancies, but contained only such things in which all Christians agree, schisms over differences of theological opinion were almost utterly vanished. Whereas to load our public forms with private fancies upon which we differ is the most sovereign way to perpetuate schism unto the world's end: prayer, confession, thanksgiving, reading of Scriptures, administration of the sacraments in the plainest and simplest manner were matter enough to furnish out a sufficient liturgy, though nothing either of private opinion or of church pomp, of garments, of prescribed gestures, of imagery, of music, of matter concerning the dead, or of many superfluities which creep into the church under the name of order and decency did interpose itself. ${ }^{14}$

Little as Hales sympathized with William Laud's ceremonialism, he found the narrow Calvinist dogmatism of many of the revolutionary forces in the Civil War even more distasteful, so, choosing between what he perceived to be two evils, he chose that which he regarded as the lesser of the two and sided with the Royalist Party. Writing against the Calvinist demand for uniformity of dogma, Hales deplores "that exceeding affection and love of our own concepts through which we cannot with patience either admit of the opinions of others, or endure that our own should be withstood...Scarcely can there be found a thing more harmful to religion than to vent thus our own concepts and obtrude them upon the world as necessary and absolute". He concludes:

It is not the variety of opinions, but our own perverse wills which think it meet that all must hold the same concepts that we hold: this it is which has so much inconvenienced the church's peace. ${ }^{15}$

At the close of his paper on Schism, Hales ends with another pithy metaphor: "If one attends a cock-fight, where serpents do the fighting, who

Hales, Works, I: 127.

George, Seventeenth Century Men of Latitude, 38.

PERICHORESIS 10.2 (2012) 
cares which side has the better? The best wish is that both may perish in the fight". ${ }^{16}$

During the Interregnum period of Oliver Cromwell's Holy Commonwealth, Calvinism and Puritanism appeared at first to be supremely victorious. Yet, as far as high Calvinism in England was concerned it was, at the very time of its apparent triumph that it was being undermined by the growth of a theological method represented by John Hales, along with other members of the Circle at Great Tew-a method which was placing greater emphasis on the valid use of human reason, thereby anticipating what, after the Restoration of 1660, was to become the Royal Society with its more positive approach to the study of physical nature based on rational observation and induction. ${ }^{17}$

\section{Bibliography}

Primary Source

Hales, John. Collected Works of John Hales. Three volumes. New York, NY: AMS Press, 1971.

Secondary Sources

Cragg, G. A. From Puritanism to the Age of Reason. A Study of Changes in Religious Thought, within the Church of England 1660-1700. Cambridge: Cambridge University Press, 1966.

George, Edward Augustus. Seventeenth Century Men of Latitude. Forerunners of the New Theology. New York, NY: Charles Scribner's Sons, 1908.

McAdoo, Henry R. The Spirit of Anglicanism. A Survey of Anglican Theological Method in the Seventeenth Century. New York, NY: Charles Scribner's Sons, 1965.

Schaff, Philip. The Creeds of Christendom with a History and Critical Notes. 3 vols. New York, NY: Harper and Brothers, 1877.

Tulloch, John. Rational Theology and Christian Philosophy in England in the Seventeenth Century. Second edition. Two volumes. Edinburgh, 1874.

16 Hales, Works, I: 132.

17 G. A. Cragg, From Puritanism to the Age of Reason. A Study of Changes in Religious Thought, within the Church of England, 1660-1700 (Cambridge: Cambridge University Press, 1966). 